\title{
Practice theory and change in international law: theorizing the development of legal meaning through the interpretive practices of international criminal courts
}

\author{
Nora Stappert* (iD) \\ Centre of Excellence for International Courts (iCourts), Copenhagen University, Faculty of Law, \\ Karen Blixens Plads 16, 2300 Copenhagen, Denmark \\ ${ }^{*}$ Corresponding author. Email: nora.stappert@jur.ku.dk
}

(Received 17 July 2018; revised 1 March 2019; accepted 1 July 2019; first published online 29 October 2019)

\begin{abstract}
The question of change has emerged as one of the main conceptual and empirical challenges for International Relations' practice turn. In the context of international law, such a challenge is brought into particularly stark relief due to the significant development of legal meaning through more informal, interpretive avenues, including through the judgments of international courts. This paper develops a framework for theorizing how interpretive legal practices generate normative content change in international law. Specifically, it uses the example of the development of international criminal law through the decisions of international criminal courts to analyze how legal interpretation can lead to normative change in practice. Drawing on interviews conducted with judges and legal officers at the International Criminal Court (ICC), the International Criminal Tribunal for the former Yugoslavia (ICTY), the International Criminal Tribunal for Rwanda (ICTR), and the Special Court for Sierra Leone (SCSL), I analyze how a community of legal practice centered around these courts was able to construct and alter legal meaning in international criminal law, and how such a potential for change was curbed by understandings of the interpretive process and the role of international courts dominant among international lawyers.
\end{abstract}

Keywords: international practices; practice turn; international relations theory; international law; international criminal court; legal interpretation

In international law, the tension between legal provisions as indeterminate on the one hand, and as stabilizing international affairs on the other is an almost classic paradox. After all, attempts by NGOs to convince states to sign international human rights treaties are rooted in the expectation that this would bind them to stable, agreed-upon standards in the future. Nevertheless, this expectation conflicts with the prominently argued view of 'the international legal system as a whole reproduction in any medium, provided the original work is properly cited. 
[that] ... lack[s] the capacity of providing coherent justification' (Koskenniemi 2005, 62). Even beyond this core tension, also the way in which international law is made and develops itself seems to have changed over time. As Nico Krisch (2014) diagnosed, not only has there been an increased use of non-legal mechanisms such as unilateral action, but also a shift toward more informal law-making processes (see also Pauwelyn, Wessel and Wouters 2012). While international organizations have assumed an increasingly prominent role in the making of international law (e.g. Alvarez 2006; Venzke 2012), especially international courts have developed international law significantly since the end of the Cold War (e.g. Von Bogdandy and Venzke 2012). Indeed, judicial law-making by international courts has even been declared to be 'omnipresent' within the international legal order (Von Bogdandy and Venzke 2012, 5).

International criminal law is one legal subfield in which the development of normative content through judicial decisions has been particularly pronounced (see e.g. Cassese 2008 , 9). The law of war crimes, for instance, was altered substantially through international adjudication (see e.g. Danner 2006; Darcy 2010). Another example is the law of command responsibility, which constitutes a way of holding military commanders accountable for international crimes committed by their subordinates (e.g. Cryer 2010). Such adjudicative developments have often exceeded the realm of minor technicalities. Instead, these legal developments at least have the potential to directly affect an assessment of the legality of the military conduct of states, not only by a state's own legal officers, but also by international criminal law experts more generally (see e.g. Scharf 2013, 153). Consequently, Allison Danner and Erik Voeten (2010, 70-71) argued that the way in which international courts developed international criminal law requires additional research precisely because they estimated that many of these far-reaching developments would probably not have been agreed upon by states during formal treaty negotiations.

To account for this substantial development of legal meaning through more informal, interpretive processes such as judicial law-making, International Relations' (IR) practice turn seems to be particularly well-suited. After all, as Friedrich Kratochwil (1989) famously pointed out, legal reasoning is practical reasoning, so that the ways in which international lawyers interpret legal provisions can be understood as a set of social practices. Within IR's broader practice turn, especially the concept of communities of practice - and more specifically, interpretive communities - promises to provide important insights into the potential for legal developments and the epistemic limits of legal creativity in international law. ${ }^{1}$ Based on the idea that international lawyers and judges share common views and professional understandings of how international law should be interpreted, the concept of interpretive communities emphasizes how legal interpretations suggested at the international plane are judged as valid or not by a community of international lawyers (Johnstone 2011, 33-41; Venzke 2011, 120-21; D'Aspremont 2015, 18, 22). In other words, how international judges

\footnotetext{
${ }^{1}$ In this context, I view interpretive communities as a specific type of community of practice. On the concept of interpretive communities, see especially Fish (1980, 14-15) and Johnstone (2005; 2011, 3354). On the concept of communities of practice, see especially Wenger (1998, 72-85), Lave and Wenger (1991), Adler (2005), and Adler and Pouliot (2011b, 17).
} 
make legal arguments occurs within, and is assessed by, a community of legal specialists who share - and at times disagree upon - a set of professional assumptions on how international law should be interpreted. While certainly not the only approach within IR's by now famously heterogeneous practice turn that might provide valuable insights (see e.g. Bueger and Gadinger 2014), for the purposes of this paper, the concept of interpretive communities was chosen as a particularly fruitful lens to theoretically account for, and empirically trace, interpretive change in international law.

At the same time, an analysis of normative content change through interpretive legal practices has the important potential to contribute to recent debates on change in international practices (Duvall and Chowdhury 2011, 347-51; Schindler and Wille 2015; Hopf 2018; Wallenius 2019, 117-18). At least in its variant broadly following-up on Adler and Pouliot's (2011a, 2011b) contributions, the potential of IR's practice turn to account for change has been identified as one of its main conceptual and empirical challenges (Duvall and Chowdhury 2011, 347-51; Villumsen Berling 2012, 451, 455; Bueger and Gadinger 2014, 65; Ringmar 2014, 17-20; Schindler and Wille 2015, 331-32; Kustermans 2016, 180-82; Hopf 2018; Cooper and Cornut 2019, 307-09). While such a potential (and perceived) challenge is not necessarily shared by alternative attempts to draw on, for example, Bourdieu's sociology to study international politics and law (Bigo 2011), and especially with regard to studies that highlight the emergence and evolution of different transnational fields (e.g. Madsen 2011; Christensen 2015), the need to avoid overly static and structuralist applications was nevertheless similarly voiced as a concern (Leander 2011; see also more recently Martin-Mazé 2017). While the paper more narrowly focuses on the concept of interpretive communities, it might therefore also be of interest to this research strand, and especially as one possible response to Leander's $(2011,296-301)$ call to account for uncertainty within international practices. After all, as Raymond Duvall and Arjun Chowdhury (2011, 347, 350) emphasized, important analytical traction can be gained by using practice theory to analyze change, for instance to understand how linguistic concepts change through practice. The development of legal meaning through, for example, international courts in turn points to a similar question: how can we theorize change in legal meaning through the interpretive practices of international law?

The paper answers this question by proposing an alternative way of theorizing change through the practices of international law, and, more specifically, to theoretically account for the development of legal meaning through (judicial) interpretation. This paper therefore follows-up on Duvall and Chowdhury's (2011, 343-47) suggestion to consider the malleable, developing, and potentially inconsistent meanings practices are based on and enact. In Duvall and Chowdhury's (2011, 343) words, '[p]ractices become such only against an existing context of meaning, or background knowledge. And practices take form within a "community of practice", which gives them meaning as competence.' However, what a practice means is inherently unstable, given that a signifier's meaning depends on how it is understood in relation to other signifiers, so that meaning can differ across audiences and over time (Duvall and Chowdhury 2011, 344; see also Schindler and Wille 2015, 331-38, 345-54). For example, judicial law-making can be understood either as increasing legal certainty, and therefore as an achievement, or be rejected as 
judicial activism, as courts are seen as overstepping their responsibilities by assuming legislative functions. Indeed, especially in international law where international courts are traditionally understood as dispute settlement mechanisms confined to merely applying legal provisions, the extent to which these courts can and should develop law is itself contested (e.g. Venzke 2011; Von Bogdandy and Venzke 2012, 6-7). How such ambiguity on the meaning of a practice may lead to change, however, still remains unclear, not only empirically, but also theoretically (see also Duvall and Chowdhury 2011, 347).

In this paper, I address this challenge by theorizing, and demonstrating empirically, how uncertainty about how to interpret existing law allows for normative content change, and how such a potential for judicial creativity is constrained by perceptions - and contestations - on the character of international law and international courts shared among legal specialists. Instead of theorizing legal meaning as entirely unstable and inconsistent, I outline how judges developed normative content through backwards-looking interpretive practices specific to legal norms, which in turn limit the possibility of more sudden and less incremental changes. To theoretically enrich the concept of interpretive communities, I thereby take inspiration from Schindler and Wille's (2015) approach that locates the potential for change within practices themselves. In this view, legal change through interpretation is possible because, while interpretive legal practices are characterized by the need to be presented as rooted in existing law, diverging views of how to understand such existing law exist for each new legal situation. More specifically, I argue that to understand how gradual, but nevertheless substantial legal change is rooted within practices, legal theory can itself be used as a reflection of assumptions on the legal interpretive process that may be shared within and across interpretive communities. Based on this argument, I not only distinguish between three reasons for interpretive discretion voiced within legal theory, but also trace in how far these reasons resonate with how judges and legal officers working at international criminal courts perceive of the potential for legal change and the appropriate role of international courts in enacting it. I then use the example of the interpretation of customary law at international criminal courts to empirically trace how legal change becomes possible, and how it is curbed by - potentially contested - assumptions about the appropriate role of international courts dominant among judges and court legal officers.

The paper therefore speaks to IR's practice turn and its account of change and normative development more broadly, and also beyond the paper's empirical focus on change through international criminal courts. Specifically, the conceptualization of legal interpretation as a set of backwards-looking practices in which it is constantly uncertain how to understand existing law is applicable more broadly to other legal regimes as well as to non-judicial legal contexts. This is not to imply that, for instance with regard to the types of legal provisions that are particularly prevalent, a different picture may not emerge across legal regimes. As I will outline in more detail below, the potential for legal creativity was especially pronounced during the early stages of the work of international criminal courts. However, the general distinction between three reasons for disagreement within interpretive legal practices I propose in this paper, as well as the general conceptualization of interpretive practices as backwards-looking, is likely to apply beyond international 
criminal law as well. Indeed, while the need to root interpretations in existing law arguably translates into a prevalence of references to previous judicial decisions across international courts (e.g. Manley 2016; Alschner and Charlotin 2018; Stappert 2018, 971-72), also in the non-judicial context of the Security Council, decision-making is shaped by the anticipation that such decisions are likely to set precedents (Johnstone 2005, 198-99). In other words, while international courts are particularly prone to develop law by setting precedents, within the horizontal, fragmented, and often weakly institutionalized structure of international law, they might not be the only interpreters assuming such an influential position (see e.g. Venzke 2012).

At the same time, it should be noted that this paper nevertheless focuses on one particular type of change: gradual, but nevertheless possibly substantial change through legal interpretation. Consequently, such changes may amount to more than 'incremental changes at the margins' confined to legal technicalities (Hopf $2018,706)$, but instead have the potential to constitute far-reaching developments of normative content. However, I argue that due to the backwards-looking character of legal interpretation, such normative content change is not random, but patterned especially through its constant reference to precedents. Such gradual change thus also becomes potentially directional, even though it is beyond the scope of this paper to trace such a direction for and across individual legal provisions. Furthermore, and especially in the nascent field of international criminal law, this is not to say that interpretive legal developments are free of internal contradictions (see especially van Sliedregt and Vasiliev 2014). As I will argue in more detail below, there may well be disagreement within an interpretive community both on the meaning of individual legal provisions and on the character of legal interpretation and international law more generally (see e.g. Bianchi 2009). This account therefore also does not focus on more sudden, and less incremental forms of change.

Finally, the paper adds more broadly to IR's understanding of interpretation and normative content change in international law. While central to International Law (IL) scholarship (e.g. Venzke 2012; Bianchi, Peat and Windsor 2015), legal interpretation has received comparatively little attention in IR. Indeed, as Jeffrey Dunoff and Mark Pollack $(2013,637)$ observed, one of the limitations of 'existing IL/IR scholarship in this area is its almost exclusive emphasis on judicial behavior [i.e. in favor of which party judges rule] and its relative neglect of legal interpretation per se [i.e. the legal justifications judges provide in support of such a ruling].' Moreover, through its empirical discussion, the paper exploits the considerable empirical potential of IR's practice turn. As has been pointed out (e.g. Bueger 2014, 384; Bode 2018, 294), contributions to IR's practice turn have at times and almost paradoxically - remained surprisingly theoretical. Nevertheless, it is one of the main promises of IR's practice turn that it is able to capture the day-to-day practices of, for example, international lawyers both empirically and theoretically. Such a potential is exemplified by the empirical and theoretical richness of several strands of, among others, Bourdieu-inspired work within and around International Political Sociology (as just some examples, see e.g. Dezalay and Garth 1996; Bigo 2011; Dezalay and Madsen 2012; Kauppi and Madsen 2014). By analyzing how international judges have responded to the potential for 
interpretive development in practice, the paper contributes to attempts to follow-up on this promise specifically for the concept of interpretive communities.

The paper begins with a brief examination of existing accounts of development and change within IR's practice turn. It proceeds to contrast this discussion with a short overview of how and to which extent international courts developed international criminal law, which gives particular attention to the way in which the process has been perceived by judges and legal officers themselves. After outlining the main framework for understanding normative content change, I then turn to a discussion of three reasons for interpretive change articulated within legal theory. The paper concludes by using the example of the development of customary law through international criminal courts, and the assumptions judges and legal officers working at these courts hold about it, as an empirical illustration. The paper draws on interviews with former and current judges and legal officers working at the International Criminal Court (ICC), the International Criminal Tribunal for the former Yugoslavia (ICTY), the International Criminal Tribunal for Rwanda (ICTR), and the Special Court for Sierra Leone (SCSL). ${ }^{2}$ In addition to judges, interviews have been conducted with legal officers working at Chambers, who are often deeply involved in the judgment-drafting process (Webb 2013, 193-94).

\section{IR's practice turn and the possibility of interpretive change}

IR's practice turn, and its burgeoning application to international law (Brunnée and Toope 2011; Meierhenrich 2014; Rajkovic, Aalberts and Gammeltoft-Hansen 2016; Aalberts and Venzke 2017; Dunoff and Pollack 2018a; Dunoff and Pollack 2018b; Wallenius 2019; arguably also Kratochwil 2014), is a particularly fruitful lens for accounting for the practices of interpretation in international law theoretically, and to research them empirically. In particular, practice theory constitutes an opportunity to gain additional analytical traction on international law's more specifically legal, but potentially politically relevant aspects that shape the day-to-day engagement of international lawyers with the international legal order. As put by Jens Meierhenrich $(2014,6)$, using practice theory therefore allows for a focus on the 'everyday products of international law,' such as the decisions and interpretations of international courts. Through such a focus, it for example facilitates empirical research on how legal meaning as interpreted by legal experts is assessed within an interpretive community (see similarly Holtermann and Madsen 2015).

The value of this growing interest in international law in IR's practice turn is underlined by the fact that such research can draw on a rich strand of sociological, and often Bourdieu-inspired, scholarship on international law (e.g. Madsen 2011; Vauchez 2012; Holtermann and Madsen 2015; Christensen 2017). Indeed, such an approach even has the potential of leaving disciplinary boundaries behind altogether (as recently suggested by Rajkovic, Aalberts and Gammeltoft-Hansen 2016; Aalberts and Venzke 2017). The parallel concepts of interpretive communities and communities of practice are a prominent example for such an opportunity

\footnotetext{
${ }^{2} \mathrm{~A}$ list of author interviews is added in the Appendix. Unless interviewees opted to be referred to by name, interviews were generally anonymized. To ensure anonymization within a comparatively small group of individuals, references do not distinguish between current and former judges and legal officers.
} 
(see Rajkovic, Aalberts and Gammeltoft-Hansen 2016), given the growing attention both concepts have received in international legal scholarship as well as within IR's practice turn (e.g. Adler 2005; Bianchi 2009; Adler and Pouliot 2011b; Bueger 2013; D’Aspremont 2015; Waibel 2015; Hofius 2016; Hernández 2017).

Applying the insights of IR's practice turn to the interpretive development of international criminal law more specifically, however, also poses one key conceptual challenge: the question how to theorize legal change through practice. To begin with, in Emanuel Adler and Vincent Pouliot's (2011b) influential work, practices are conceptualized as rooted in shared understandings, or 'background knowledge,' which in turn is learned and enacted through practice within the social setting of communities of practice. At least at first glance, however, one difficulty then becomes how exactly this process may lead to change. Potential answers provided by Adler and Pouliot include the suggestion to focus on the performative element of practices, as meaning has to be constantly reconstituted and hence cannot be stable, or the suggestion that interacting practices may lead to change (Adler and Pouliot 2011b, 16-21). Possibly due to the challenges of generating insights applicable across different practices and communities of practice, and even though Adler and Pouliot (2011b, 18-21) explicitly highlight the centrality of the question of change, these valuable suggestions arguably provide but a starting point for further, more detailed examinations of why and how exactly meaning might develop in one direction or another, and when and why such a development would begin in the first place.

One way of thinking about the challenge of accounting for change is that in this view, it is the focus on repetition and routine based on common, learned assumptions or 'background knowledge' that provides the concept of practices with its structural - instead of merely agential - dimension (Adler and Pouliot 2011b, 8, 15). In Adler and Pouliot's framework (2011a, 5), practices are seen as distinct from mere behavior or action in that they constitute 'patterned actions that are embedded in particular organized contexts ... and are socially developed through learning and training.' In other words, if there was no pattern, nothing that could be learned through repetition, practices would be reduced to a set of unstructured actions - and therefore arguably become conceptually irrelevant (see most recently also Cooper and Cornut 2019, 308). After all, while analyzing a practice that only occurs once might be interesting in and of itself, such an analysis cannot provide insights beyond this occurrence, and consequently runs the danger of being confined to mere description.

As a consequence, in Adler and Pouliot's words (Adler and Pouliot 2011b, 7), the potential for change becomes limited to the 'wiggle room' within this continuous process of repetition. After all, as they point out, practices only exist as they are enacted (Adler and Pouliot 2011b, 7). A (endogenous) potential for change thus emerges as these practices are enacted each time within a unique social situation, as well as within social structures that themselves develop over time. However, if change is confined to such a 'wiggle room' as practices are enacted in an ever-fluid world, change becomes to be seen as non-directional - and potentially negligible. As Jorg Kustermans $(2016,182)$ points out, if we were to follow such a view, 'change would morph into chance'. Another concern that has been voiced is that this view does not seem to indicate why and how exactly change emerges (Bially Mattern 2011, 72, fn. 40; Hopf 2018, 692). Finally, as Ted Hopf (2018) points 
out, such a conceptualization does not capture more far-reaching forms of change. Applied to international adjudication, it seems to be in tension with the gradual, but nevertheless substantial and potentially directional development of normative content through judicial law-making.

However, within IR's practice turn, several authors have recently added to (and questioned) this conceptualization of change in practices, identifying different forms of change (Villumsen Berling 2012, 455-56, 468-69; Ringmar 2014, 1720; Schindler and Wille 2015; Hopf 2018). Specifically with regard to change in international law, Jutta Brunnée and Stephen Toope (2010, 2018a, 2018b, 2019) recently extended their 'interactional' framework to argue that legal change and contestation are rooted in, and constrained by, the continued assessment of legal norms as fulfilling the requirements of legality. As in their earlier work, they base their approach on the work of Lon Fuller, and identify a set of legality requirements including promulgation, non-retroactivity, constancy, and clarity (Brunnée and Toope 2010). Taken together, Brunnée and Toope's approach thereby makes a number of important contributions. First and foremost, their work theorizes the distinctive character of international law and legal obligation (Brunnée and Toope 2010, 2011). Furthermore, by conceptualizing the possibility of contestation and change in international law despite an inherent tendency for stability, Brunnée and Toope's approach underlines the considerable benefit that can be gained by analyzing international legal change through the lens of practice theory. Finally, they fruitfully highlight not only the stabilizing role of 'background knowledge' that delineates the 'parameters' of legal interpretation, but also conceptualize the practices of legality as enacted within a community of practice (Brunnée and Toope 2018b, 438; 2010, 2011).

Within recent attempts to apply practice theory to international law (and beyond), Brunnée and Toope' approach therefore provides a major contribution to our understanding of legal change in practice. At the same time, their thought-provoking approach also opens up a number of new questions. From a legal perspective, Nico Krisch (2012) previously challenged Brunnée and Toope's application of Fuller's work to international law, among others because of international law's horizontal structure and its traditional focus on states as subjects. From a more empirically-driven perspective, their approach also raises the question how far there might be differences in the ways in which different subgroups of legal specialists embedded in different social contexts - or, in other words, potentially overlapping, but distinct interpretive communities - perceive of and engage with international law (see also especially Roberts 2017). Due to their attempt to theorize international law's distinctiveness, Brunnée and Toope's comprehensive framework might be less suited to account for such potential differences. After all, in a situation in which an application of their framework would find adherence to the principle of clarity within a specific regime and its practice to be weak, for example, it would lead to the conclusion that the legal regime in question is supported by an overall weaker practice of legality. It would not lead to the question whether the particular subset of international lawyers that is being studied might share a potentially diverging set of background understandings on international law and how to interpret it. While Brunnée and Toope's framework therefore constitutes an important starting point, it remains unclear how we can understand legal change if we want to go beyond a pre-set list of 
legality requirements, and instead empirically research the '[taken] for granted ... markers of competent legal argumentation' while still accounting for international law's distinctiveness (Brunnée and Toope 2018b, 438).

In another notable recent contribution, and beyond international law, Hopf $(2018,692)$ distinguishes between endogenous, more incremental types of change as discussed above (what he calls 'change in practice through practice'), and more far-reaching forms of change that, according to him, are rooted in conscious deliberation. Through this account, Hopf aptly highlights how IR's practice turn has overlooked the role of conscious deliberation when theorizing international practices. Consequently, he emphasizes how, for example, such reflection is inherent to the process of becoming socialized within a community of practice (Hopf $2018,690)$. At the same time, Hopf characterizes the 'slippage' that occurs when (general) rules are applied to (specific) situations as a form of 'unintentional change' (Hopf 2018, 693). Drawing on Wittgenstein, he concludes that ' $\mathrm{t}]$ here is no precise correspondence between the rules that govern everyday social life and the unique features of social life encountered every day ... we must necessarily "improvise" when applying any rule, and in so doing, we change what the rule means in practice' (Hopf 2018, 693). He further argues that such a potential for change through 'improvisation' is unlikely to be (consciously) identified due to the breadth of potential ways in which meaning can be expressed linguistically (Hopf 2018, 693). By situating change in the meaning of rules through interpretive practices squarely within the realm of the non-intentional and unreflective, Hopf also assumes that such changes in meaning are necessarily 'non-directional' as well as located 'largely at the margins' (Hopf 2018, 693, 705).

As I will outline in more depth below, however, in the case of interpretive legal practices in international criminal law, Hopf's characterization of endogenous change as minimal and non-conscious, as well as Adler and Pouliot's view of such change as non-directional, is at odds with the significant development of normative content through the interpretive practices of international courts, as well as with the patterned character of this development. Instead, I draw on Schindler and Wille's (2015) alternative account of change in international practices, ${ }^{3}$ who in more detail challenged Pouliot's interpretation of his own empirical material to explain change within the practices of the NATO-Russia Council. Specifically, they argue that the potential for change arose because it was contested among actors how the past should be interpreted in practice (Schindler and Wille 2015, 331-39, 345-54). In other words, while still relying on the notion of repetition, Schindler and Wille point out that at any moment in time, competing interpretations of the past may exist. They therefore take the conceptually crucial step of specifying one way in which (potentially substantial) change may be situated within practices themselves, instead of conceptualizing more far-reaching forms of change as rooted externally (Schindler and Wille 2015, 338, 346).

\footnotetext{
${ }^{3}$ Hopf incorporates Schindler and Wille's approach within his framework, emphasizing how different views of the past led to conscious reflection and thus substantial change. However, this account sidesteps the question how and why such a divergence was substantial enough to trigger deliberation in the first place, and why it did not remain confined to the realm of non-reflective 'improvisations' (Hopf 2018, 693, 704).
} 
In the interpretive practices of international law, the potential for change in legal meaning can similarly best be understood as rooted within these interpretive practices themselves. In particular, it is one of the core - and distinctive - features of the interpretive legal process that it is backwards-looking, constantly claiming that its interpretations are grounded in existing law. Similar to a contested view of the past as outlined by Schindler and Wille (2015), the application of rules to actual situations is far from a straight-forward process, and frequently allows for discretion, for example with regard to how to interpret two conflicting rules. Contrary to both Hopf's and Adler and Pouliot's approach, however, the resulting changes in legal meaning may not be confined to marginal developments. As Kratochwil $(2011,50)$ argued, the possibility of change emerges when rules are applied to factual situations that are 'usually ambiguous,' thereby allowing for 'interstitial changes' that may indeed lead to far-reaching transformations over time. This is not to suggest that such a potential is without limits. Within the interpretive practices of international criminal law, and as I will outline below, the potential for change is curbed by potentially contested professional assumptions of a community of legal experts on the extent to which international courts should 'make' law that rule out less gradual forms of change. The following section provides a first step into this direction by briefly outlining the development of international criminal law though judicial decisions as seen by the judges and legal officers involved in this process themselves, which suggests that this development has been neither negligible nor random.

\section{Interpretive practices and change in international criminal law}

At the time the ICTY was established, the UN Secretary General had tasked the court to rely on 'existing international humanitarian law,' and to refrain from judicial law-making. ${ }^{4}$ In the practice of international and hybrid criminal courts, however, such a distinction was difficult to maintain. As Patricia Wald (2010, xxxvii), former judge at the ICTY, argued, judges at both international and domestic higher courts 'recognize early on that whatever the compulsory assurances they gave when appointed that they would only apply the law and not create it, drawing that line is not so simple in practice,' a view that was echoed by three of the judges interviewed for this project (Interviews 1, 2, and 4; but Interview 3). ${ }^{5}$ In this context, one of the judges at the ICTY pointed out that existing legal provisions often lacked specificity, and that some legal aspects were not even mentioned (Interview 1). A judge at the SCSL even went a step further by arguing that in some instances, 'there was nothing to alter or to modify, there was nothing in international law' (Interview 4).

As a result, the development of legal meaning in international criminal law through the decisions of international courts has generally been described as extensive (e.g. Danner 2006, 3). International courts altered the content of both the procedural and substantive legal rules and principles of international criminal law.

\footnotetext{
${ }^{4}$ Secretary General, Report of the Secretary General pursuant to Paragraph 2 of Security Council Resolution 808 (1993), UN Doc. S/25704, 3 May 1993, para. 28.

'Interviewee 2 referred specifically to the ad hoc Tribunals' early years. Interviewee 3 , however, argued that this quote does not reflect their experience.
} 
These legal developments ranged from forms of liability and the applicable rules of procedure to the interpretation of the elements of international crimes (Darcy and Powderly 2010a). Commentators usually referred to the strikingly 'skeletal' character of the field at the time the ICTY and the ICTR were established in 1993 and 1994, respectively, to account for its rapid development (e.g. Cassese 2008, 4-6, 9-10). In particular, while both Tribunals could only draw on the post-World War II Nuremberg and Tokyo Trials as existing case law, the legal provisions of their Statutes were lamented to provide rudimentary guidance at best (Cassese 2008, 4; Darcy and Powderly 2010b, 2; Wald 2010, xxxv). International courts were thus seen as having to specify treaty provisions, determine the existence of customary law, and generally develop what might be called legal doctrine, thereby filling legal provisions with, for example, 'tests' and 'criteria' to facilitate their application (Cassese 2008, 9).

This high degree of legal flexibility is also reflected by the perceptions of judges and legal officers working for international and hybrid criminal courts. Several of the judges and legal officers I interviewed indicated that they were repeatedly confronted with legal questions for which the law had remained unclear (Interviews 1, $2,3,4,5,8,12$, and 15). This legal flexibility was particularly pronounced during the initial phase of the work of international and hybrid criminal courts: in the view of these legal practitioners, significant legal developments occurred during the first years following the establishment of the ad hoc Tribunals, such as the decision to use Joint Criminal Enterprise as a form of liability (Interviews 2, 12, 14, 15, and 17). As a legal officer at the ICTR claimed, '[i]n the early days, ... it was a whole development of a whole new system' (Interview 12).

While this potential for legal change was more muted during the later stages of the work of these courts, this is not to suggest that the potential for further judicial developments was precluded. By the time the interviews for this project were conducted more than 20 years after the establishment of the ICTY and the ICTR, new legal issues continued to arise (Interview 8). Such new legal questions often emerged at the Appeals level and concerned procedural aspects (Interviews 15 and 17). ${ }^{6}$ And even though the Rome Statute is considerably more elaborate than the Statutes of the ad hoc Tribunals, the creation of the ICC did not seem to have entailed a decrease in the potential for judicial creativity. Instead, legal officers and judges lamented that also the Rome Statute, the ICC's Rules of Evidence and Procedure, and the Elements of Crimes were filled with gaps and contradictions (Interviews 6, 7, and 13), with an ICC judge indicating that the potential for judicial creativity exists especially with regard to procedural law (Interview 7). The ICC is consequently still required, in the words of one legal officer, to 'travel a lot of uncharted territor[y]' (Interview 13).

How have international judges responded to this relatively high degree of interpretive freedom, and how can we understand such a noticeable potential for judicial creativity and interpretive change? The following discussion outlines a framework for understanding normative content change through interpretive legal practices.

\footnotetext{
${ }^{6}$ Specifically, interviewee 15 referred to the former point, while interviewee 17 observed that a large number of legal developments that occurred after 2005 concerned procedural questions.
} 


\section{Theorizing change through the interpretive practices of international law}

As mentioned above, I draw on the concept of interpretive communities to theorize normative content change in international law. Within IR's heterogeneous practice turn, my approach therefore resonates most closely with work that uses the concept of communities of practice (e.g. Adler 2005; Adler and Pouliot 2011b; Bueger 2013; Hofius 2016). To understand interpretive change in international law, the concept of interpretive communities is especially useful as it highlights how new interpretations are assessed as valid or not within a community of international lawyers (Johnstone 2011, 33-41; D’Aspremont 2015, 18, 22). Specifically, it emphasizes that, while there might be considerable room to propose different legal interpretations, professional assumptions shared among international lawyers about the process of legal interpretation - such as the assumption that a court's interpretation should generally be consistent with previous case law - imposes limits on which legal views are ultimately accepted (see similarly Johnstone 2011, 36). Such a process therefore continuously re-negotiates the outer limits of which interpretations are likely to be assessed as valid by an interpretive community.

Despite its growing popularity, the concept of interpretive communities - as well as communities of practice - entails two main drawbacks. First, the concept's communitarian focus implies a sense of coherence among international lawyers and a lack of contestation between the different interpretations they propose that is likely to be misleading (see similarly Vauchez 2014, 662-63). Second, beyond highlighting that legal interpreters require acceptance from their peers, it almost becomes an empty concept from a theoretical standpoint. After all, it does not provide any guidance as to which interpretations will be assessed as valid and why (similarly Venzke 2016, 11-12; for an overview of this debate, see D'Aspremont 2015, 221).

To avoid both challenges, the concept of interpretive communities in my view needs to be filled both theoretically and empirically with an outline of specific traits of interpretive practices and shared professional assumptions on which they are based, and an analysis of potential tensions within and among them. For the purposes of this paper, I propose that a core distinguishing feature of interpretive legal practices is that they are backwards-looking, as each legal interpretation needs to be justified as rooted in already existing law (see also Venzke 2012, 48-49; D’Aspremont 2015, 219-20). In Pierre Bourdieu's (1987, 845) words, the 'work [of judgments] of formalizing and systematizing ... ties the present continuously to the past.' One may object that such a view is at odds with the 'utopian,' teleological side of international law (Koskenniemi 2005, 2011). However, the point here is to suggest that legal interpretations nevertheless need to at least be convincingly presented as rooted in existing law. Furthermore, by arguing that interpretive legal practices are backwards-looking, it should be noted that I am not proposing a variant of legal positivism in disguise. Instead, interpreters can draw on different types of legal documents that are considered to possess what Ingo Venzke $(2012,63)$ has called 'semantic authority,' that is, 'an actor's capacity to influence and shape meanings as well as the ability to establish its communications as authoritative reference points in legal discourse.'

At the same time, by referring back to legal texts that are constructed as authoritative, international legal practices are based on the assumption that the 
interpretations they produce are rooted at least indirectly in - and, in the case of judicial interpretation, proclaimed on behalf of - an authority that is portrayed as both legitimate and external to the interpretive community itself. As Bourdieu $(1987,838)$ outlined for the domestic context, '[ $t$ ] he judgment represents the quintessential form of authorized, public, official speech which is spoken in the name of and to everyone.' Despite the lack of a centralized legislator in international law, traces of the same position can be found in the view of international law as grounded in state consent (as implied by the sources doctrine, see e.g. Venzke 2011, 107-10; 2012, 16-27).

Specifically with regard to international courts, these backwards-looking interpretive practices translate into the 'myth' of judges as merely applying rules to specific cases, instead of using discretion or even making law, which plays a crucial role in legitimizing judicial decisions (see also Venzke 2011, 105-07; Hernández 2015, 181). It also accounts for the prevalence of the use of precedents by international courts, even though precedents are not formally binding at the international level. For example, the International Court of Justice (ICJ) does not have to follow its own previous interpretations in subsequent cases. ${ }^{7}$ Despite this formal rule, in practice, international courts including the ICJ frequently refer to their own and potentially each other's decisions (e.g. Manley 2016; Alschner and Charlotin 2018; Stappert 2018, 971-72). Even in the non-judicial setting of the UN Security Council, Johnstone (2005, 198-99) showed how diplomats negotiating resolutions are aware that their legal justification of a particular behavior will set an informal, but nevertheless potentially influential precedent that will later be referred to by the interpretive legal community.

Through this specifically backwards-looking character, interpretation within the interpretive community of international law (or, more likely, several overlapping interpretive legal communities clustered around different legal regimes) becomes distinct from the interpretation of other norms. It is thus the backwards-looking character of interpretive practices as rooted in an authority portrayed as outside of the community of legal practice itself that is key to understanding the distinctiveness (and, indeed, perceived and constructed legitimacy) of international law. As a consequence of this requirement to convince other members of the interpretive community that an interpretation is based on existing law, such a perspective entails that interpretive change in international law, even if potentially significant, is typically incremental and excludes more sudden forms of change. Especially in the context of international adjudication, it thereby furthers reliance on precedents as previous interpretations of existing law. It should be noted that, at least to a certain extent, this perspective thus shares some common ground with especially Brunnée and Toope's (2018b) account of change in international law. After all, by emphasizing the centrality of a set of legality requirements, including the need for constancy and clarity, they equally highlight how legal change becomes gradual. However, by identifying the backwards-looking character of interpretive legal practices as a more general core feature of interpretive legal practices, this account seeks to go beyond a fixed list of legality requirements inspired by Fuller.

${ }^{7}$ See articles 38(1)(d) and 59 of the Statute of the ICJ. 
This does not mean, however, that there is no room for disagreement within interpretive communities, or that interpretive change is necessarily consistent or uncontroversial. To give just one example, international courts might draw on a previous precedent, but then be criticized by other members of the interpretive community for misconstruing it. To conceptualize change through interpretive practices, I take inspiration from Schindler and Wille's (2015) view of change as developing from within international practices. As they argue, key to understanding change is that while practices are shaped by views of the past, at any point in time, how to understand the past is contested, which they see as a process that can be traced empirically. In Schindler and Wille's $(2015,350)$ words, their analysis is therefore not so much 'concerned with the truth of descriptions of the past, but with how practitioners use such descriptions to make sense of the present.' Applied to international law understood as a set of backwards-looking interpretive practices, Schindler and Wille's perspective is useful as it highlights a similar disagreement about the past as enacted in practice. However, instead of focusing on disagreement of past political events such as the Cold War, in international law, disagreement centers around how to understand existing law with regard to specific legal questions, and which interpretations of existing legal rules, doctrines, and principles moves too far into the direction of law-making and is thus invalid.

In international law, Schindler and Wille's conceptualization resonates with Holtermann and Madsen's (2015) proposal to empirically research the construction of legal validity by international lawyers in practice. Specifically, they suggest that, instead of seeing the rules and doctrines that lawyers draw on to argue that a legal position is valid (and on whose interpretation they might disagree) in themselves as a way to discover (internal, legal) truth, legal validity should be researched empirically (Holtermann and Madsen 2015, 213-21). Drawing on Max Weber and Alf Ross, they therefore emphasize the distinction between 'axiological and empirical validity' (Holtermann and Madsen 2015, 216). Similarly, I propose that even the views about the very character of international law that legal practitioners hold and enact in their legal practice, as well as the role of international courts in making international law, can be researched empirically. In other words, and in line with scholarship that uses sociological approaches to trace how different groups of lawyers theorize about international law (e.g. Bianchi 2016), whether or not international courts make international law is not only subject to scholarly debate, but is also reflected in empirically researchable views that international judges hold about their role, and which they reenact in practice.

In my framework, and parallel to the distinction between axiological and empirical validity, legal theory thus plays a dual role. First, it can help theorize when and how disagreement about the interpretation of existing law may occur, and under which conditions normative development through interpretation might be possible. Specifically, in the subsequent section, I will outline three partly overlapping reasons why international lawyers might disagree about the interpretation of existing law extant in legal theory. As I will argue below, however, these three reasons are based on different conceptions of the potential for interpretive discretion, and ultimately the character of international law itself. Traces of such different conceptions, in turn, can be found in the views that judges and legal officers themselves hold of the interpretive process and their role within it, and can thus be researched 
empirically. In my framework, legal theory therefore indirectly also plays a second, empirical role. In the interpretive practices of judges and lawyers at international courts, differing perspectives about the appropriate role of international courts within the international law-making process thus play out in concerns among judges and legal officers about not going 'too far' as not to undermine the legitimacy of courts on the one hand, and outside observers arguing that international criminal tribunals 'invented' law on the other. In the end, given the prevalence of views on judicial interpretation as (merely) filling 'gaps,' within the interpretive community, the expectation of judicial constraint thus ultimately curbs the potential for change through international judicial law-making in practice.

\section{Three reasons for legal change through interpretative practices}

In legal theory, the question of flexibility in legal meaning, and especially the amount of discretion that judges have when deciding cases, is a central point of discussion. ${ }^{8}$ Specifically, judicial flexibility is at the heart of the long-standing and surprisingly sticky debate between formalism and legal realism (Solum 2014, 2495). Most importantly, legal realists challenged the supposition that a rule's phrasing constrains a judge's interpretation. Given that this fundamental critique formed the basis of much subsequent work (such as most notably critical legal studies scholarship), formalism seems to have degraded into an almost entirely fictional position within the debate that is only ever debunked, but never defended. ${ }^{9}$ Indeed, Ronald Dworkin $(1998,6,8)$ called a conception of adjudication as a technical (rather than a creative or productive) process the layman's version of the 'plain-fact view' of law: the assumption that 'there is law in the books decisive of every issue that might come before a judge.' Instead of discussing whether judges are bound to technically enforce legal provisions or not, the more important questions - and the cause of real disagreement in legal theory - concentrate on inquiries into the nature and limits of judicial flexibility and interpretive change.

For the purposes of this paper, I will (necessarily briefly) outline three categories of more conceptual approaches that differ with regard to the reasons for why judges may have substantial latitude when making their decisions: the phrasing of legal provisions; different types of legal provisions; and the structure of legal reasoning itself. These reasons should not be understood to be mutually exclusive, but rather complementary to each other. Additionally, they partly rely on different conceptions of law, which, in turn, leads to differences in how judicial discretion - and thereby the potential for creativity and change - is conceptualized and how extensive it is estimated to be.

\section{'Gaps' in the phrasing of legal provisions}

To begin with the first reason, common among international lawyers is the view that judges are, at least to a certain extent, constrained in their legal interpretation,

\footnotetext{
${ }^{8}$ I will focus on the insights that can be gained from these debates specifically on judicial discretion, even though most of these aspects equally apply to legal interpretation more generally, and regardless of the institutional role of the interpreter and the legal status of the resulting interpretive product.

${ }^{9}$ This point has already been observed by Dworkin $(1978,15-16)$, even though the debate does not seem to have changed much in this regard since. In Weinrib's $(2005,332)$ words, '[r] umor has it that legal formalism is dead'.
} 
and that a judge's discretion is instead grounded in the intentional or unintentional 'gaps' contained in the phrasing of a specific legal provision. According to this common narrative that also featured prominently in the perceptions of judges and legal officers outlined above, judges are occasionally confronted with legal provisions that do not provide them with a clear answer. ${ }^{10}$ These ambiguities might be the result of imperfection, as they may, for example, arise from unforeseen factual circumstances that have not been considered by the legislature when drafting a particular statute. As another example, imperfection may also result from conflicting legal rules. In any legal system, instances may arise in which more than one legal rule is applicable, and it might be the case that those rules stipulate conflicting legal conclusions. Joseph Raz $(1979,74-75)$ hence concluded that 'gaps' in the law also exist when no rule is provided that regulates how to resolve such a conflict.

In the context of the increasing complexity of international law, the absence of legal provisions that regulate such conflicts might be particularly prevalent. Consequently, for example Vaughan Lowe $(2000,212-19)$ argued that it may be this creation of new 'interstitial norms' resolving such norm conflicts by judges that will constitute one of the most important developments in international law in the future. As an alternative, legal provisions may also be ambiguous or vague by design. In international law specifically, Kenneth Abbott and Duncan Snidal (2000, 433), for example, argued that due to the complexity of the required negotiation process, states frequently decide to leave legal provisions ambiguous. As judges (usually) cannot refer the question back to the legislature, they nevertheless have to make a decision, thereby 'filling' the 'gap' with their legal interpretation. ${ }^{11}$ Within contemporary international law, both intentional and unintentional 'gaps' in the phrasing of existing legal provisions therefore play a prominent role in accounting for judicial discretion.

Interestingly, this first reason resonated most closely with how the legal officers and judges I interviewed perceived of legal change through judicial interpretation. In particular, a view of legal change as rooted in the imperfect phrasing of legal provisions was commonly implied by interviewees who, as outlined above, pointed toward a perceived lack of specificity or clarity of legal provisions, or toward internal contradictions or 'gaps' in the ICC's statutory framework as reasons for the development of international criminal law. Nevertheless, in legal theory, important alternative (and partly overlapping) accounts of how interpretation may develop legal content exist.

\section{Types of legal provisions that allow for greater latitude}

Instead of confining judicial latitude to situations in which the legislature intentionally or unintentionally created 'gaps,' arguably also certain types of legal provisions generally provide judges with a particularly high degree of leeway. If seen from this perspective, it does not matter how carefully legal provisions are drafted, as some types of laws will always provide judges with more latitude than others. In particular, a common way of distinguishing between different types of legal provisions is to

\footnotetext{
${ }^{10}$ According to $\operatorname{Raz}(1979,70)$, ' $[t]$ here is a gap in the law when a legal question has no complete answer'.

${ }^{11}$ In this context, Raz $(1979,96)$, for example, argues that the use of judicial discretion to complete 'gaps' in the law, in combination with the doctrine of precedent, may often amount to judicial law-making.
} 
contrast legal rules with legal standards. According to Dworkin (1978, 24), rules and principles 'differ in the character of the direction they give.' As he explained, while a rule is either applicable or not depending on whether the necessary conditions are fulfilled, principles instead give reasons that might guide the decision in one direction or another. Principles hence have to be taken into account by judges, but unlike rules, they allow for more than a choice between the applicability and non-applicability of a certain legal conclusion (Dworkin 1978, 24-25).

Types of legal provisions that due to their character allow for more latitude than others can thus be conceptualized as a second reason for legal flexibility. In international law, especially the conventional distinction between different sources of international law - namely international treaties, customary provisions, and general principles of law as listed in article 38(1) of the Statute of the International Court of Justice - comes to mind. However, inspired by Dworkin, it can be argued that customary provisions can differ substantially from international treaties in the direction they provide, especially due to their non-codified character. In other words, the meaning of customary provisions is likely to be contested because of the very character of customary law as not stipulated explicitly in treaty-form.

This is not to imply that customary law always leaves more room for legal creativity than treaty law. After all, and as noted above, treaties may well be worded in a way that leaves substantial interpretive latitude. Furthermore, it should be noted that there is some overlap between these two reasons for interpretive disagreement discussed so far. As Dworkin $(1978,28)$ points out, in cases in which a legal rule includes, for example, the term 'reasonable,' this rule comes to act as a principle, hence providing judges with discretion. $\operatorname{Raz}(1979,194)$, on the other hand, uses legal rules that include a reasonableness standard as an example for instances in which the legislature intentionally left 'gaps' for judges to fill.

\section{Creativity as inherent to the legal reasoning process}

Finally, while certain types of legal provisions that form a fundamental part of every legal system provide more leeway for judges than others, one can even go further and argue that it is the structure of the legal reasoning process itself that generally allows for considerable latitude. As $\operatorname{Raz}(1979,73)$ argues, legal indeterminacy is inevitable, not only because at a linguistic level, every text lacks clarity to a certain extent, but also because this text needs to be applied to social facts that themselves are frequently inconclusive. After all, it is judges who, when considering the admissibility of evidence, decide which parts of reality may be included into the narrative that is considered by a court, and how much legal weight is conferred to them. As Kratochwil (2000b, 40) put it, 'even explicitly formulated rules can do little until they are applied to concrete situations.' Or, in Martti Koskenniemi's $(2005,61)$ words, 'one man's "aggression" is another's "self-defence".'

Based on this outline of three reasons for legal creativity, the following section draws on interviews with judges and legal officers to illustrate how legal meaning is changed through the judgments of international criminal courts in practice. Specifically, I will focus on the interpretation of customary law, and trace how assumptions about its interpretation voiced by judges and legal officers have provided limits for legal change in practice. 


\section{Between creativity and conservatism: legal interpretation in practice}

At the time the ICTY was created, the UN Secretary General tasked the court to rely on customary provisions of international humanitarian law that 'beyond any doubt' constitute international custom. ${ }^{12}$ This requirement had been deemed as particularly crucial to satisfy the nullum crimen sine lege principle, necessitating that every crime that is prosecuted needs to have been criminalized by the time it was committed. ${ }^{13}$ In the jurisprudence of international and hybrid criminal courts, however, the very determination of whether a specific provision constituted part of international custom - and the professional assumptions underlying it - frequently provided international judges with substantial interpretive latitude (see similarly Tzevelekos 2016, 192-205).

As the arguably most visible example, the ICTY relied on international custom to prosecute war crimes not explicitly enumerated in the court's Statute. In one of its earliest decisions, the Tadic Jurisdiction Decision, the ICTY Appeals Chamber held that the list of crimes included in article 3 of the ICTY Statute was openended, so that other crimes under customary and treaty law could fall within the court's jurisdiction as well. ${ }^{14}$ An example for such an unenumerated crime is the crime of terror against the civilian population. In Galić, the ICTY Appeals Chamber determined that this crime constituted part of international custom and entailed individual criminal responsibility. ${ }^{15}$ Consequently, in the judicial development of the law of war crimes, the prevalence of customary law - and the need to determine its past existence - has arguably played a prominent role in allowing for legal developments.

Some of the judges and legal officers interviewed for this project explicitly recognized such a potential for creativity inherent in the interpretation of international custom. Indeed, it can be concluded that the expectation that the interpretive step of determining the existence of international custom provides for legal flexibility formed part of the assumptions shared by these legal practitioners. For example, Judge Howard Morrison, judge at the ICTY and the ICC, described international custom as 'an amorphous creature' requiring 'a slow but creative process' (Interview 8). Furthermore, a legal officer at the ICTR explained that

although technically if you say it is customary international law, then it is not technically developing it, but it's ... a nice way of pushing the development a little bit... It is sort of codifying and explicitly stating ... looking for a bunch of principles all over the place, bringing them all together, doing a thorough analysis of it and then stating it (Interview 12).

\footnotetext{
${ }^{12}$ Secretary General, Report of the Secretary General pursuant to Paragraph 2 of Security Council Resolution 808 (1993), UN Doc S/25704, 3 May 1993, para. 34.

${ }^{13}$ See similarly Secretary General, Report of the Secretary General pursuant to Paragraph 2 of Security Council Resolution 808 (1993), UN Doc S/25704, 3 May 1993, para. 34. See also, for example, article 22 of the ICC Statute.

${ }^{14}$ See Prosecutor v. Tadić, Decision on the Defence Motion for Interlocutory Appeal on Jurisdiction, ICTY Appeals Chamber Decision, Case No. IT-94-1, 2 October 1995, para. 87.

${ }^{15}$ See Prosecutor v. Galić, ICTY Appeals Chamber Judgment, Case No. IT-98-29-A, 30 November 2006, paras. 86-98.
} 
As this statement emphasizes, the legal flexibility provided by customary rules is especially rooted in the non-codified character of this specific type of legal provision (see similarly Powderly 2010, 26). As a result, it is part of the interpretive practices of international criminal courts to take an additional step when interpreting international custom by establishing whether these legal provisions exist in customary law in the first place. Such a determination may then be used as a starting point in the future. An example is the decision of the SCSL to hold that a prohibition of using, enlisting, or conscripting child soldiers exists in international customary law and entailed individual criminal responsibility. ${ }^{16}$ As a judge at the SCSL observed, 'it is from that very moment' in which this decision was delivered that this offence 'was accepted by the ... United Nations and the states, and that [it] was created' (Interview 4). Indeed, it has been observed (at times critically) that, if a specific line of reasoning is endorsed by international criminal courts, this jurisprudence may itself become part of international customary law (Baker 2010, 175, 184-86; Van den Herik 2010, 101-02; Scharf 2013, 45-47). Such a view was explicitly confirmed by Judge Morrison, who explained that

[ j] udgments often start off as decisions based upon statutory interpretation. If that decision is followed often enough and over a lengthy period so as to be endorsed in a number of cases, it grows into the realm of customary law. I [think] that this body of certain law is a judicial achievement (Interview 8).

Within the interpretive practices of international law, determining whether a legal provision has emerged as part of international customary law involves a discussion of the existence of state practice and opinio juris as an indication that states believe that a provision is part of international law and that they follow it in practice (see e.g. Shaw 2008, 7-10; but see Baker 2010, 175). And as the ICTY held in the Tadić Jurisdiction Decision, to prosecute an individual for an international crime that is part of international customary law, the court would need to determine not only that a crime existed at the time the offence was committed, but also that it incurred individual criminal responsibility. ${ }^{17}$ While these interpretive steps therefore provide international criminal courts with a considerable degree of interpretive discretion, the specific way in which these courts have used international custom in their jurisprudence has been subject to frequent criticism by legal academics arguably forming part of the larger interpretive community surrounding these courts. These criticisms have included the suggestions that the ad hoc Tribunals have been inconsistent, that they gave too much weight to either state practice or opinio juris in their analysis, or that, given the nullum crimen sine lege principle, reliance on uncodified international customary provisions to determine specific elements of international crimes was generally inadequate (e.g. Bantekas 2006, 121; Darcy 2010, 126; Powderly 2010, 26-28; Van den Herik

\footnotetext{
${ }^{16}$ See Prosecutor v. Norman, Decision on Preliminary Motion Based on Lack of Jurisdiction (Child Recruitment), SCSL Appeals Chamber Decision, Case No. SCSL-2004-14-AR72(E), 31 May 2004, paras. $17-53$.

${ }^{17}$ See Prosecutor v. Tadić, Decision on the Defence Motion for Interlocutory Appeal on Jurisdiction, ICTY Appeals Chamber Decision, Case No. IT-94-1, 2 October 1995, para. 94.
} 
2010, 100). Indeed, some legal scholars warned that such an expansive approach may undermine the legitimacy of international criminal courts and their jurisprudence (Darcy 2010, 122-23; Powderly 2010, 32).

As these concerns illustrate, within the interpretive practices of international criminal law, discussions on the correct interpretive technique to determine the existence of customary rules intersect with assumptions on the appropriate role of judicial decision-making in international law. Indeed, it can be concluded that another professional assumption shared by legal experts concerns the idea that international courts should not overstep their responsibilities by proposing developments that are too sudden and that might be criticized for not being sufficiently rooted in existing law - even though it remains up to the assessment of others whether this requirement has been fulfilled in individual cases. Some of the judges and legal officers hence voiced caution when discussing the innovative potential of customary provisions. The legal officer cited above, for example, pointed out that while interpreting international custom was 'a nice way of pushing the development a little bit,' there was nevertheless 'a real conservatism to not to go too far.' As they explained, especially in a young legal subfield, international courts were particularly vulnerable 'to criticism of ... making up the law' (Interview 12) ${ }^{18}$ At the same time, two of the judges interviewed for this project mentioned that they were aware of the often intense academic interest their judgments were generating (Interviews 1 and 6). In the words of one legal officer, they were thus 'treading carefully, thoughtfully,' especially when relying on international customary law (Interview 12). Indeed, the concern that international criminal courts might overstep their responsibility $v i s-a$-vis the legislative functions of states seems to be a core aspect of scholarly debates and criticisms on how international courts should interpret customary international humanitarian law. In the interpretive practices of international criminal judges and legal officers, the potential for change in legal meaning provided by the ambiguous character of customary provisions was therefore limited by the assumptions held within the community of legal practice on the role of international courts within the international law-making process.

\section{Conclusions}

This paper proposed an alternative way of theorizing change in the practices of international law, and, more specifically, to theoretically account for the development of legal meaning through interpretation. In particular, I drew on Schindler and Wille's (2015) account of change in practice as rooted in uncertainty about the past to enrich the concept of interpretive communities. Specifically, I distinguished between three (partly overlapping) reasons for legal change within the backwards-looking interpretive practices of international law: intentional and unintentional 'gaps' within the phrasing of legal provisions; types of legal provisions that allow for more leeway; and the innovative potential inherent in the judicial reasoning process itself. Using the interpretation of customary provisions as an example, I showed how such a potential for legal change is nevertheless limited by

\footnotetext{
${ }^{18}$ Similarly also Judge Howard Morrison, who referred to an inherently conservative character of law that limits the potential for developing legal meaning (Interview 8).
} 
assumptions about the role of international courts and the character of international law that are wide-spread among judges and legal officers. This is not to suggest, however, that the judicial development of legal meaning in international criminal law was confined to change 'at the margins' (Hopf 2018, 706). Indeed, the interviews that I conducted emphasized that judges and legal officers were consciously aware that legal meaning in international criminal law had been developed substantially through the jurisprudence of international criminal courts, to the extent that they problematized the need not to overstep their responsibilities in the process.

The theoretical framework I developed in this paper - as well as the empirical insights on how international criminal law judges navigate the challenges of legal interpretation and change in practice - only provides a first step in the direction of a broader research agenda on interpretive practices and normative change. To begin with, additional insights could be gained by comparing the practices of legal interpretation across different legal regimes and (potentially non-judicial) interpretive contexts, and beyond this paper's focus on judicial interpretation in international criminal law. Another, particularly fruitful avenue is to examine the role of what Duvall and Chowdhury (2011, 340) have called incompetent practices.' In the interpretive practices of international law, one of the crucial questions is to which extent these practices are shared across institutional settings, and in how far some groups - and government legal advisers in particular - may purposefully challenge and ultimately be able to change them. Furthermore, additional research could build on the theoretical framework developed in this paper by exploring how interpretive practices themselves, as well as the underlying assumptions on which they are based, change over time. As one example, it may be that the interpretive practices of international law have changed with an amendment of the institutional structure of the international legal order, such as after the establishment of the ICC.

Finally, what has remained unaccounted for in this analysis of change in legal meaning in international criminal law is the normative direction of such change. As Jason Ralph and Jess Gifkins convincingly argued, practice theory not only has difficulties with capturing when, how and why change happens, but also 'has little to say about whether change, when it happens, is progressive' (Ralph and Gifkins 2017, 635). Unlike the idea of a 'wiggle room' in which change is confined to the erratic (Adler and Pouliot 2011b, 7), by referring back to previous jurisprudence, change in legal meaning through judicial interpretation may attain such a sense of direction. The question whether or not the direction of such a development has been normatively desirable, however, has been left unanswered in this paper. Indeed, it may well be the case that the way in which international criminal courts developed the law of war crimes corresponded to changing social norms, for example. ${ }^{19}$ Following-up on Ralph and Gifkins' (2017) suggestion, one particularly fruitful area for further research would therefore be to inquire whether such a development exhibited what Mervyn Frost (2009) calls 'ethical competence,' in addition to (generally) being perceived as valid by a community of international lawyers.

\footnotetext{
${ }^{19}$ For a more critical assessment, however, see Kratochwil $(2014,129-34)$.
} 
Acknowledgments. This paper draws in part on my doctoral dissertation at the University of Oxford entitled 'International Courts and Legal Innovation: The Politics and Practices of Interpretation in International Criminal Law.' I am grateful to Richard Caplan, Arjun Chowdhury, Maria Eriksson Baaz, Jakob v. H. Holtermann, Ian Johnstone, Sean Richmond, and my colleagues at Oxford, Gothenburg, and Copenhagen for their comments. I am also indebted to the helpful criticism I received at the Annual Convention of the International Studies Association in Baltimore in 2017. Finally, I would especially like to thank the two anonymous reviewers, the editors, both incoming and outgoing, as well as my doctoral supervisor, Andrew Hurrell, for their insightful comments on earlier versions of this project. All errors are mine.

Funding. This research has been funded by a Marie Skłodowska-Curie Fellowship as part of the European Commission's Horizon 2020 Research and Innovation Programme, and by the Danish National Research Foundation Grant No. DNRF105. It was partly conducted under the auspices of the Danish National Research Foundation's Centre of Excellence for International Courts (iCourts).

\section{References}

Aalberts, Tanja, and Ingo Venzke. 2017. "Moving Beyond Interdisciplinary Turf Wars: Towards an Understanding of International Law as Practice." In International Law as a Profession, edited by Jean D'Aspremont et al., 287-310. Cambridge: Cambridge University Press.

Abbott, Kenneth, and Duncan Snidal. 2000. "Hard and Soft Law in International Governance." International Organization 54(3):421-56.

Adler, Emanuel. 2005. Communitarian International Relations: The Epistemic Foundations of International Relations. Abingdon: Routledge.

Adler, Emanuel, and Vincent Pouliot. 2011a. "International Practices." International Theory 3(1):1-36.

Adler, Emanuel, and Vincent Pouliot. 2011b. "International Practices: Introduction and Framework." In International Practices, edited by Emanuel Adler and Vincent Pouliot, 3-35. Cambridge: Cambridge University Press.

Alschner, Wolfgang, and Damien Charlotin. 2018. "The Growing Complexity of the International Court of Justice's Self-Citation Network." European Journal of International Law 29(1):83-112.

Alvarez, José. 2006. International Organizations as Law-Makers. Oxford: Oxford University Press.

Baker, Roozbeh. 2010. "Customary International Law in the 21st Century: Old Challenges and New Debates." European Journal of International Law 21(1):173-204.

Bantekas, Ilias. 2006. "Reflections on Some Sources and Methods of International Criminal and Humanitarian Law." International Criminal Law Review 6(1):121-36.

Bially Mattern, Janice. 2011. "A Practice Theory of Emotion for International Relations." In International Practices, edited by Emanuel Adler and Vincent Pouliot, 63-86. Cambridge: Cambridge University Press.

Bianchi, Andrea. 2009. "The International Regulation of the Use of Force: The Politics of Interpretive Method." Leiden Journal of International Law 22(4):651-76.

Bianchi, Andrea. 2016. International Law Theories: An Inquiry into Different Ways of Thinking. Oxford: Oxford University Press.

Bianchi, Andrea, Daniel Peat, and Matthew Windsor. 2015. Interpretation in International Law. Oxford: Oxford University Press.

Bigo, Didier. 2011. "Pierre Bourdieu and International Relations: Power of Practices, Practices of Power." International Political Sociology 5(3):225-58.

Bode, Ingvild. 2018. "Reflective Practices at the Security Council: Children and Armed Conflict and the Three United Nations." European Journal of International Relations 24(2):293-318.

Bourdieu, Pierre. 1987. "The Force of Law: Toward a Sociology of the Juridical Field." Hastings Law Journal 38(5):814-53.

Brunnée, Jutta, and Stephen Toope. 2010. Legitimacy and Legality in International Law: An Interactional Account. Cambridge: Cambridge University Press.

Brunnée, Jutta, and Stephen Toope. 2011. "Interactional International Law and the Practice of Legality." In International Practices, edited by Emanuel Adler and Vincent Pouliot, 108-35. Cambridge: Cambridge University Press. 
Brunnée, Jutta, and Stephen Toope. 2018a. "Self-Defence against Non-State Actors: Are Powerful States Willing but Unable to Change International Law?.” International \& Comparative Law Quarterly 67 (2):263-86.

Brunnée, Jutta, and Stephen Toope. 2018b. "International Law and the Practice of Legality: Stability and Change." Victoria University of Wellington Law Review 49(4):429-45.

Brunnée, Jutta, and Stephen Toope. 2019. "Norm Robustness and Contestation in International Law: Self-Defense against Nonstate Actors." Journal of Global Security Studies 4(1):73-87.

Bueger, Christian. 2013. "Communities of Security Practice at Work? The Emerging African Maritime Security Regime.” African Security 6(3-4):297-316.

Bueger, Christian. 2014. "Pathways to Practice: Praxiography and International Politics." European Political Science Review 6(3):383-406.

Bueger, Christian, and Frank Gadinger. 2014. International Practice Theory: New Perspectives. Basingstoke: Palgrave Macmillan.

Cassese, Antonio. 2008. International Criminal Law. Oxford: Oxford University Press.

Christensen, Mikkel Jarle. 2015. "From Symbolic Surge to Closing Courts: The Transformation of International Criminal Justice and its Professional Practices." International Journal of Law, Crime and Justice 43(4):609-25.

Christensen, Mikkel Jarle. 2017. "Preaching, Practicing and Publishing International Criminal Justice: The Role of Academic Expertise in the Development of an International Field of Law." International Criminal Law Review 17(2):239-58.

Cooper, Andrew, and Jérémie Cornut. 2019. "The Changing Practices of Frontline Diplomacy: New Directions for Inquiry." Review of International Studies 45(2):300-19.

Cryer, Robert. 2010. "The Ad Hoc Tribunals and the Law of Command Responsibility: A Quiet Earthquake." In Judicial Creativity at the International Criminal Tribunals, edited by Joseph Powderly and Shane Darcy, 159-83. Oxford: Oxford University Press.

Danner, Allison, and Erik Voeten. 2010. "Who is Running the International Criminal Justice System?." In Who Governs the Globe?, edited by Deborah Avant et al., 35-71. Cambridge: Cambridge University Press.

Danner, Allison Marston. 2006. "When Courts Make Law: How the International Criminal Tribunals Recast the Laws of War." Vanderbilt Law Review 59(1):1-65.

Darcy, Shane. 2010. "The Reinvention of War Crimes by the International Criminal Tribunals." In Judicial Creativity at the International Criminal Tribunals, edited by Shane Darcy and Joseph Powderly, 106-28. Oxford: Oxford University Press.

Darcy, Shane, and Joseph Powderly. 2010a. Judicial Creativity at the International Criminal Tribunals. Oxford: Oxford University Press.

Darcy, Shane, and Joseph Powderly. 2010b. "Introduction." In Judicial Creativity at the International Criminal Tribunals, edited by Shane Darcy and Joseph Powderly, 1-13. Oxford: Oxford University Press.

D'Aspremont, Jean. 2015. Epistemic Forces in International Law: Foundational Doctrines and Techniques of International Legal Argumentation. Cheltenham: Edward Elgar.

Dezalay, Yves, and Bryant Garth. 1996. Dealing in Virtue: International Commercial Arbitration and the Construction of a Transnational Legal Order. Chicago: University of Chicago Press.

Dezalay, Yves, and Mikael Rask Madsen. 2012. "The Force of Law and Lawyers: Pierre Bourdieu and the Reflexive Sociology of Law." Annual Review of Law and Social Science 8:433-52.

Dunoff, Jeffrey, and Mark Pollack. 2013. "Reviewing Two Decades of IL/IR Scholarship: What We've Learned, What's Next." In Interdisciplinary Perspectives on International Law and International Relations: The State of the Art, edited by Jeffrey Dunoff and Mark Pollack, 626-62. Cambridge: Cambridge University Press.

Dunoff, Jeffrey, and Mark Pollack. 2018a. "International Judicial Practices: Opening the 'Black Box' of International Courts." Michigan Journal of International Law 40(1):47-113.

Dunoff, Jeffrey, and Mark Pollack. 2018b. "A Typology of International Judicial Practices." In The Judicialization of International Law: A Mixed Blessing?, edited by Andreas Follesdal and Geir Ulfstein, 86-106. Oxford: Oxford University Press.

Duvall, Raymond, and Arjun Chowdhury. 2011. "Practices of Theory." In International Practices, edited by Emanuel Adler and Vincent Pouliot, 335-54. Cambridge: Cambridge University Press.

Dworkin, Ronald. 1978. Taking Rights Seriously. London: Duckworth. 
Dworkin, Ronald. 1998. Law's Empire. Oxford: Hart Publishing.

Fish, Stanley. 1980. Is There a Text in This Class? The Authority of Interpretive Communities. Cambridge: Harvard University Press.

Frost, Mervyn. 2009. "Ethical Competence in International Relations." Ethics \& International Affairs 23 (2):91-100.

Hernández, Gleider. 2015. "Interpretive Authority and the International Judiciary." In Interpretation in International Law, edited by Andrea Bianchi, Daniel Peat, and Matthew Windsor, 166-85. Oxford: Oxford University Press.

Hernández, Gleider. 2017. "The Responsibility of the International Legal Academic: Situating the Grammarian within the 'Invisible College'." In International Law as a Profession, edited by Jean D'Aspremont et al., 160-88. Cambridge: Cambridge University Press.

Hofius, Maren. 2016. "Community at the Border or the Boundaries of Community? The Case of EU Field Diplomats." Review of International Studies 42(5):939-67.

Holtermann, Jakob v. H., and Mikael Rask Madsen. 2015. "European New Legal Realism and International Law: How to Make International Law Intelligible." Leiden Journal of International Law 28(2):211-30.

Hopf, Ted. 2018. "Change in International Practices." European Journal of International Relations 24 (3):687-711.

Johnstone, Ian. 2005. "The Power of Interpretive Communities." In Power in Global Governance, edited by Michael Barnett and Raymond Duvall, 185-204. Cambridge: Cambridge University Press.

Johnstone, Ian. 2011. The Power of Deliberation: International Law, Politics and Organizations. Oxford: Oxford University Press.

Kauppi, Niilo, and Mikael Rask Madsen. 2014. "Fields of Global Governance: How Transnational Power Elites Can Make Global Governance Intelligible.” International Political Sociology 8(3):324-30.

Koskenniemi, Martti. 2005. From Apology to Utopia: The Structure of International Legal Argument. Cambridge: Cambridge University Press.

Koskenniemi, Martti. 2011. "Law, Teleology and International Relations: An Essay in Counterdisciplinarity." International Relations 26(1):3-34.

Kratochwil, Friedrich. 1989. Rules, Norms, and Decisions: On the Conditions of Practical and Legal Reasoning in International Relations and Domestic Affairs. Cambridge: Cambridge University Press.

Kratochwil, Friedrich. 2000. "How Do Norms Matter?" In The Role of Law in International Politics: Essays in International Relations and International Law, edited by Michael Byers, 35-68. Oxford: Oxford University Press.

Kratochwil, Friedrich. 2011. "Making Sense of 'International Practices'." In International Practices, edited by Emanuel Adler and Vincent Pouliot, 36-60. Cambridge: Cambridge University Press.

Kratochwil, Friedrich. 2014. The Status of Law in World Society: Meditations on the Role and Rule of Law. Cambridge: Cambridge University Press.

Krisch, Nico. 2012. "Review of: Legitimacy and Legality in International Law by Jutta Brunnée and Stephen Toope." American Journal of International Law 106(1):203-9.

Krisch, Nico. 2014. "The Decay of Consent: International Law in an Age of Global Public Goods." American Journal of International Law 108(1):1-40.

Kustermans, Jorg. 2016. "Parsing the Practice Turn: Practice, Practical Knowledge, Practices." Millennium 44(2):175-96.

Lave, Jean, and Etienne Wenger. 1991. Situated Learning: Legitimate Peripheral Participation. Cambridge: Cambridge University Press.

Leander, Anna. 2011. "The Promises, Problems, and Potentials of a Bourdieu-Inspired Staging of International Relations." International Political Sociology 5(3):294-313.

Lowe, Vaughan. 2000. "The Politics of Law-Making: Are the Method and Character of Norm Creation Changing?." In The Role of Law in International Politics: Essays in International Relations and International Law, edited by Michael Byers, 207-26. Oxford: Oxford University Press.

Madsen, Mikael Rask. 2011. "Reflexivity and the Construction of the International Object: The Case of Human Rights." International Political Sociology 5(3):259-75.

Manley, Stewart. 2016. "Referencing Patterns at the International Criminal Court." European Journal of International Law 27(1):191-214.

Martin-Mazé, Médéric. 2017. "Returning Struggles to the Practice Turn: How Were Bourdieu and Boltanski Lost in (Some) Translations and What to Do about It?" International Political Sociology 11(2):203-20. 
Meierhenrich, Jens. 2014. "The Practice of International Law: A Theoretical Analysis." Law and Contemporary Problems 76(3):1-83.

Pauwelyn, Joost, Ramses Wessel, and Jan Wouters. 2012. Informal International Lawmaking. Oxford: Oxford University Press.

Powderly, Joseph. 2010. "Judicial Interpretation at the Ad Hoc Tribunals: Method from Chaos?." In Judicial Creativity at the International Criminal Tribunals, edited by Shane Darcy and Joseph Powderly, 17-44. Oxford: Oxford University Press.

Rajkovic, Nikolas, Tanja Aalberts, and Thomas Gammeltoft-Hansen. 2016. The Power of Legality: Practices of International Law and their Politics. Cambridge: Cambridge University Press.

Ralph, Jason, and Jess Gifkins. 2017. "The Purpose of United Nations Security Council Practice: Contesting Competence Claims in the Normative Context Created by the Responsibility to Protect." European Journal of International Relations 23(3):630-53.

Raz, Joseph. 1979. The Authority of Law: Essays on Law and Morality. Oxford: Oxford University Press.

Ringmar, Erik. 2014. "The Search for Dialogue as a Hindrance to Understanding: Practices as Inter-Paradigmatic Research Program." International Theory 6(1):1-27.

Roberts, Anthea. 2017. Is International Law International?. Oxford: Oxford University Press.

Scharf, Michael. 2013. Customary International Law in Times of Fundamental Change: Recognizing Grotian Moments. Cambridge: Cambridge University Press.

Schindler, Sebastian, and Tobias Wille. 2015. "Change in and Through Practice: Pierre Bourdieu, Vincent Pouliot, and the End of the Cold War." International Theory 7(2):330-59.

Shaw, Malcolm. 2008. International Law. Cambridge: Cambridge University Press.

Solum, Lawrence. 2014. "The Positive Foundations of Formalism: False Necessity and American Legal Realism." Harvard Law Review 127(8):2464-97.

Stappert, Nora. 2018. "A New Influence of Legal Scholars? The Use of Academic Writings at International Criminal Courts and Tribunals." Leiden Journal of International Law 31(4):963-80.

Tzevelekos, Vassilis. 2016. "Juris Dicere: Custom as a Matrix, Custom as a Norm, and the Role of Judges and (their) Ideology in Custom Making." In The Power of Legality: Practices of International Law and their Politics, edited by Nikolas Rajkovic, Tanja Aalberts and Thomas Gammeltoft-Hansen, 188-208. Cambridge: Cambridge University Press.

Van den Herik, Larissa. 2010. "Using Custom to Reconceptualize Crimes Against Humanity." In Judicial Creativity at the International Criminal Tribunals, edited by Shane Darcy and Joseph Powderly, 80-105. Oxford: Oxford University Press.

Van Sliedregt, Elies, and Sergey Vasiliev. 2014. Pluralism in International Criminal Law. Oxford: Oxford University Press.

Vauchez, Antoine. 2012. "Keeping the Dream Alive: The European Court of Justice and the Transnational Fabric of Integrationist Jurisprudence." European Political Science Review 4(1):51-71.

Vauchez, Antoine. 2014. "Communities of International Litigators." In The Oxford Handbook of International Adjudication, edited by Cesare Romano et al., 655-68. Oxford: Oxford University Press.

Venzke, Ingo. 2011. "The Role of International Courts as Interpreters and Developers of the Law: Working Out the Jurisgenerative Practice of Interpretation." Loyola of Los Angeles International and Comparative Law Review 34(1):99-131.

Venzke, Ingo. 2012. How Interpretation Makes International Law: On Semantic Change and Normative Twists. Oxford: Oxford University Press.

Venzke, Ingo. 2016. "International Law as an Argumentative Practice: On Wohlrapp's The Concept of Argument." Transnational Legal Theory 7(1):9-19.

Villumsen Berling, Trine. 2012. "Bourdieu, International Relations, and European Security." Theory and Society 41(5):451-78.

von Bogdandy, Armin, and Ingo Venzke. 2012. "Beyond Dispute: International Judicial Institutions as Lawmakers." In International Judicial Lawmaking, edited by Armin von Bogdandy and Ingo Venzke, 3-34. Heidelberg: Springer.

Waibel, Michael. 2015. "Interpretive Communities in International Law." In Interpretation in International Law, edited by Andrea Bianchi, Daniel Peat, and Matthew Windsor, 147-65. Oxford: Oxford University Press.

Wald, Patricia. 2010. "Note From the Bench." In Judicial Creativity at the International Criminal Tribunals, edited by Shane Darcy and Joseph Powderly, xxxv-xl. Oxford: Oxford University Press. 
Wallenius, Tomas. 2019. "The Case for a History of Global Legal Practices." European Journal of International Relations 25(1):108-30.

Webb, Philippa. 2013. International Judicial Integration and Fragmentation. Oxford: Oxford University Press.

Weinrib, Ernest. 2005. "Legal Formalism." In A Companion to Philosophy of Law and Legal Theory, edited by Dennis Patterson, 332-42. Oxford: Blackwell Publishing.

Wenger, Etienne. 1998. Communities of Practice: Learning, Meaning, and Identity. Cambridge: Cambridge University Press.

\section{Appendix: Author interviews}

Author Interview 1 (2015). Judge at the ICTY, 9 December, The Hague.

Author Interview 2 (2015). Judge at the ICTR, 15 December, phone interview.

Author Interview 3 (2015). Judge at the ICTY, 18 December, The Hague.

Author Interview 4 (2016). Judge at the SCSL, 6 February, Kingston Upon Thames.

Author Interview 5 (2015). Judge at the ICTR, 25 November, phone interview.

Author Interview 6 (2015). Judge Piotr Hofmański, Judge at the ICC, 26 November, The Hague.

Author Interview 7 (2015). Judge Cuno Tarfusser, Judge at the ICC, 26 November, The Hague.

Author Interview 8 (2015). Judge Howard Morrison, Judge at the ICTY and the ICC, 16 December, The Hague.

Author Interview 12 (2015). Legal officer at the ICTR, 5 December, The Hague.

Author Interview 13 (2015). Legal officer at the ICC, 5 December, The Hague.

Author Interview 14 (2015). Legal officer at the ICTY, 10 December, The Hague.

Author Interview 15 (2016). Legal officer at the ICTR, 26 January, The Hague.

Author Interview 17 (2015). Thomas Wayde Pittman, Former Acting Head of Chambers, ICTY, 3 December 2015, The Hague.

Cite this article: Stappert, N. 2020. "Practice theory and change in international law: theorizing the development of legal meaning through the interpretive practices of international criminal courts." International Theory 12, 33-58, doi:10.1017/S1752971919000150 